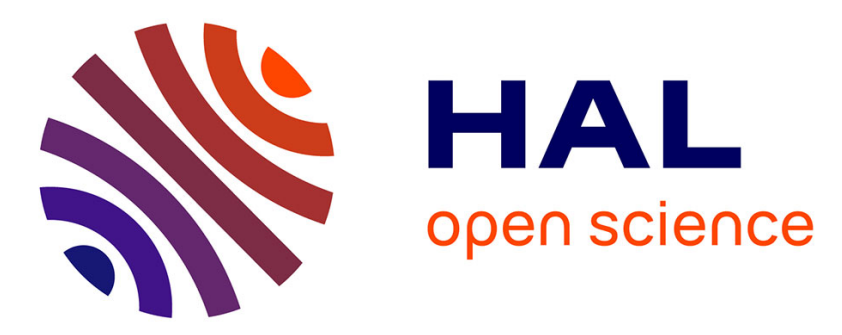

\title{
Person-Organization Congruence and the Maintenance of Group-Based Social Hierarchy: A Social Dominance Perspective
}

\author{
Hillary Haley, Jim Sidanius
}

\section{To cite this version:}

Hillary Haley, Jim Sidanius. Person-Organization Congruence and the Maintenance of Group-Based Social Hierarchy: A Social Dominance Perspective. Group Processes and Intergroup Relations, 2005, 8 (2), pp.187-203. 10.1177/1368430205051067 . hal-00571602

\section{HAL Id: hal-00571602 https://hal.science/hal-00571602}

Submitted on 1 Mar 2011

HAL is a multi-disciplinary open access archive for the deposit and dissemination of scientific research documents, whether they are published or not. The documents may come from teaching and research institutions in France or abroad, or from public or private research centers.
L'archive ouverte pluridisciplinaire HAL, est destinée au dépôt et à la diffusion de documents scientifiques de niveau recherche, publiés ou non, émanant des établissements d'enseignement et de recherche français ou étrangers, des laboratoires publics ou privés. 


\title{
Person-Organization Congruence and the Maintenance of Group-Based Social Hierarchy: A Social Dominance Perspective
}

\author{
Hillary Haley and Jim Sidanius \\ Department of Psychology, UCLA
}

\begin{abstract}
Using vocational choice theory and social dominance theory as guiding frameworks, this paper examines the interrelationships between the types of social institutions that a person occupies, on the one hand, and the sociopolitical attitudes and behavioral predispositions that a person displays, on the other. Beginning with Holland (1959, 1966), numerous researchers have documented the fact that people's work-related values tend to match the values of their work environments. Researchers have also found, as we might expect, that this value match yields superior job performance and greater employee satisfaction. Social dominance theory has proposed an important expansion of this research: people's sociopolitical attitudes (e.g. antiegalitarianism) should also be compatible, or congruent, with their institutional environments (e.g. schools, workplaces). A growing body of research supports this claim. Specifically, recent research has shown that hierarchy-enhancing (HE) organizations (e.g. police forces) tend to be occupied by those with anti-egalitarian beliefs, while hierarchy-attenuating (HA) organizations (e.g. civil liberties organizations) tend to be occupied by those with relatively democratic beliefs. This research has also provided evidence for five (non-mutually exclusive) processes underlying this institutional assortment: self-selection, institutional selection, institutional socialization, differential reward, and differential attrition. This paper reviews the literature bearing on each of these processes, and suggests key paths for future research.
\end{abstract}

KEYWORDS anti-egalitarianism, college major, institutions, organizations, person-environment fit, social dominance orientation, social dominance theory, social hierarchy, social roles, socialization, vocational choice

\author{
Author's note \\ Address correspondence to Jim Sidanius, \\ Department of Psychology, University of \\ California, Los Angeles, 405 Hilgard Avenue, \\ Los Angeles, CA 90095-1563, USA \\ [email: Sidanius@psych.ucla.edu]
}


DURING the last 40 years, there has been a steady stream of research on worker-workplace 'fit'-the idea that people can be psychologically 'matched' to different occupational settings. This research was largely pioneered by Holland (1959, 1966), who was among the first to suggest that occupational choices function as expressive acts. As Holland saw it, people seek out occupations that suit their inclinations and motivations (e.g. 'artistic' or 'entrepreneurial') - just as, for example, people are apt to eat foods that suit their tastes. Holland further thought the secret to job satisfaction is in the fit; the greater the person-environment (P-E) congruence, the deeper an employee's satisfaction should be. Finding the right job, it was argued, is as much about a person's psychology as it is about a person's skills and abilities.

Vocational and organizational psychologists have produced a substantial body of research in support of Holland's reasoning. The bulk of this work has focused on P-E congruence in terms of values (e.g. concern for others, interest in financial gains, attention to detail). Researchers have found that people's central values do indeed tend to be congruent with the values prevailing in their work environments (e.g. Adkins, Russell, \& Werbel, 1994; Ben-Shem \& Avi-Itzhak, 1991; Holland, 1996; Posner, 1992; Rynes \& Gerhart, 1990). Moreover, researchers have found that such P-E value congruence corresponds to heightened job satisfaction, greater job commitment, and diminished turnover intentions (e.g. see Assouline \& Meir, 1987; Bretz \& Judge, 1994; Cable \& Judge, 1996; Chatman, 1989, 1991; Gottfredson \& Holland, 1990; Joyce \& Slocum, 1982; Meglino, Ravlin, \& Adkins, 1989; Meir, 1995; O'Reilly, Chatman, \& Caldwell, 1991; Tranberg, Slane, \& Ekberg, 1993; Vancouver \& Schmitt, 1991).

Consistent with these findings, it has also been shown that $\mathrm{P}-\mathrm{E}$ value congruence goes hand in hand with superior employee performance (see, e.g. Adkins, Ravlin, \& Meglino, 1996; Boxx, Odom, \& Dunn, 1991; Chatman, 1991; Chatman \& Barsade, 1995; Goodman \& Svyantek, 1999; Gottfredson \& Holland, 1990; Holland, 1966, 1985; Jehn, Chadwick, \& Thatcher, 1997; Joyce \& Slocum, 1982;
Kemelgor, 1982; Kuo, Cheng, \& Wang, 2001; Meglino et al., 1989; Mount \& Muchinsky, 1978; O'Reilly et al., 1991; Posthuma \& Navran, 1970; Tokar, Fischer, \& Subich, 1998; see also O'Reilly \& Chatman, 1996). In brief, this research suggests not only that value congruence is normative, but also that it is beneficial to both worker and workplace alike.

In recent years, social dominance theorists (e.g. Pratto \& Espinoza, 2001; Pratto, Sidanius, Stallworth, \& Malle, 1994; Pratto, Stallworth, Sidanius, \& Siers, 1997; Sidanius \& Pratto, 1999; Sidanius, Pratto, Sinclair, \& van Laar, 1996; Sidanius, van Laar, Levin, \& Sinclair, 2003; van Laar, Sidanius, Rabinowitz, \& Sinclair, 1999) have suggested that a similar P-E 'fit' exists for sociopolitical attitudes. In the same way that people who place a premium on moneymaking tend to work in environments that do the same, it is expected that people who endorse the subordination of others tend to inhabit environments that produce the subordination of others. Put differently, social dominance theorists argue that there should be a positive correlation between an individual's attitudes vis-a-vis inter-group equality and his/her organization's impact on existing inter-group inequalities.

In this paper, we examine evidence for such a sociopolitical 'fit'. We begin by reviewing several relevant tenets of social dominance theory, including the distinction between hierarchyenhancing (HE) and hierarchy-attenuating (HA) institutions. Next, we take stock of the growing body of literature-by social dominance theorists and by others-that provides support for the idea of sociopolitical 'fit'. We then turn to a discussion of the processes believed to guide this sociopolitical 'fit'. Following the lead of the occupational congruence literature, social dominance theory posits five (non-mutually exclusive) processes: selfselection, institutional selection, institutional socialization, differential rewards, and differential attrition (see van Laar et al., 1999). We examine evidence for each of these processes in detail. Finally, this paper also identifies lacunae in this stream of research, and suggests some key directions for future work. 
Our goals in this review are therefore threefold: (1) we intend to show that there is in fact a positive correlation between people's intergroup attitudes and their respective organizations' relationships to existing group inequalities; (2) we seek to demonstrate that this correlation is maintained by at least five specific-though likely interrelated-processes; and (3) we aim to underscore the important implications of these patterns of findings, and to identify fruitful avenues for future research. Before discussing the evidence for person-organization congruence in intergroup attitudes, a brief overview of social dominance theory is in order.

\section{Social dominance theory}

According to social dominance theory (SDT), there is a general human tendency to form and maintain group-based social hierarchies. Such hierarchies, it is argued-whether predicated upon ethnicity, class, caste, or any other social designation-can be observed within any modern human society. In all cases, one or more dominant social groups (e.g. the rich) enjoy disproportionate social advantages (e.g. high status or political power), while one or more subordinate groups (e.g. the poor) suffer disproportionate social disadvantages (e.g. poor access to healthcare or high rates of imprisonment).

Social dominance theorists posit that these social hierarchies are in large part created, preserved, and recreated by social institutions, or organizations. While lone individuals can help to strengthen these hierarchies (e.g. by voting in favor of laws that disproportionately handicap low-status groups) or to attenuate them (e.g. by voting in favor of laws that instead help to level the playing field), institutions should be able to impact hierarchies to a far greater degree. Universities, financial houses, and judicial systems, for example, can powerfully promote or suppress existing social hierarchies based on how they allocate positive resources (e.g. prestige, wealth, healthcare) and/or negative resources (e.g. disdain, poverty, endangerment). Indeed, SDT-unlike many competing theories (see, e.g. Jones, 1997)asserts that institutions play a principal role in shaping group-based hierarchies (e.g. Mitchell \& Sidanius, 1995; Pratto et al., 1997; Sidanius, Liu, Pratto, \& Shaw, 1994; Sidanius et al., 1996; van Laar et al., 1999). ${ }^{1}$

Social dominance theorists also draw a distinction between two types of institutions: HE institutions and HA institutions. Within social dominance theory HE and HA forces can be thought of as counterbalancing elements that jointly contribute to the stability of existing group-based hierarchies. HE institutions can be identified as those most likely to promote hierarchically structured relationships among social groups (e.g. economic inequalities among 'races', classes, or ethnic groups) by making disproportionately greater positive social allocations (or fewer negative social allocations) to dominant groups than to subordinate groups.

Examples of $\mathrm{HE}$ institutions are internal security organizations (e.g. SAVAK, FBI, KGB, Vlakplass), death squads, and profit-maximizing financial institutions (e.g. corporate law firms). One important HE institution is the US criminal justice system, which has been documented as imposing disproportionately harsh negative sanctions on subordinate groups (e.g. blacks and Latinos) as compared with dominant groups (e.g. whites; see also Chevigny, 1995; Cole, 1999; Kennedy, 1997; Mauer, 1999; Miller, 1996; Nelson, 2000; Parenti, 1999; Sidanius \& Pratto, 1999; Tonry, 1995; for indirect evidence see also Weitzer, 2000). While personnel within the criminal justice system may not consciously intend to discriminate, and may not even be aware of the discriminatory effects of their behavior, the system can still be considered an HE institution simply because its net result is the enactment and maintenance of group-based hierarchy and inequality.

In contrast, HA institutions offset the effects of HE institutions by defending subordinate social groups (e.g. the poor) and generally facilitating both an egalitarian distribution of positive social value and the subsequent attenuation of group-based social hierarchy. Among the more obvious examples of HA institutions are civil rights groups, civil liberties groups, 
welfare organizations, and religious organizations devoted to the protection of the poor, the vulnerable and the oppressed (e.g. followers of liberation theology). ${ }^{2}$ It should also be noted that while a given institution might be identified as an HE institution or as an HA institution, it may also contain differently flavored (HE and HA) departments or sectors; consider, for example, both (HE) prison guards and (HA) social workers within the (HE) US criminal justice system.

This distinction between HE and HA institutions is central to the claim that a P-E 'fit' exists for sociopolitical attitudes. According to this claim, HE environments will tend to be populated by supporters of group-based hierarchies, while HA environments will tend to be populated by those who reject group-based hierarchies. This line of reasoning is very congruent with Holland's (1985) assertion that any given institution functions as a 'human aggregate', exerting influence through the pooled characteristics of its members.

SDT captures people's support for groupbased hierarchies with a construct known as social dominance orientation (see Pratto et al., 1994). Social dominance orientation, while distinct from other constructs, is reliably related to belief systems such as ethnocentrism, nationalism, authoritarianism, 'racism', and sexism. Similarly, it has been found to correlate with hierarchy-related behaviors (e.g. 'racial' discrimination, stereotyping) and hierarchyrelated policy positions (e.g. death penalty views, welfare reform views, support for military conquest).

People with discriminatory convictions such as 'some groups are better than others' are said to have high levels of social dominance orientation, and should therefore be quite comfortable within HE institutions. People with egalitarian beliefs, such as 'we should strive for increased social equality between groups', on the other hand, are said to have low levels of social dominance orientation, and should be more comfortable within HA organizations (see Sidanius \& Pratto, 1999, pp. 41-44; Sidanius, Pratto, Martin, \& Stallworth, 1991). Naturally, it is also expected that sociopolitical beliefs related to social dominance orientation (e.g. xenophobia, sexism) will function in a similar manner, such that people with egalitarian beliefs should tend to 'match' with HA environments, while those with non-egalitarian beliefs should tend to 'match' with HE environments. Thus, it is argued that a person's sociopolitical 'fit', or congruence, within an institution pivots on whether the institutional environment is classifiable as HE or HA.

\section{Sociopolitical attitudes and P-E 'fit'}

As SDT would predict, a good deal of literature supports the idea that there is a P-E 'fit' with respect to sociopolitical attitudes. Interestingly, this 'fit' can be found even between college students-who commonly have very similar backgrounds and very indefinite sociopolitical attitudes-and the courses of study they pursue (e.g. Altemeyer, 1998; Guimond, 1999; Guimond, Palmer, \& Bégin, 1989; Sidanius et al., 1991, 2003; van Laar et al., 1999). Specifically, students pursuing degrees that would typically lead to HE careers (e.g. degrees in business or law) hold relatively anti-egalitarian views, while those pursuing degrees that would typically lead to HA careers (e.g. degrees in the humanities or social sciences) hold relatively egalitarian views. One of the earliest such findings was reported by Feldman and Newcomb (1969), who found less authoritarianism among students in the humanities and arts as opposed to students in other areas of study.

Recently, more fine-grained evidence of this pattern has been reported (Sidanius et al., 2003) in research with UCLA students. In this research, the authors identified lists of majors that could be clearly classified as 'HE majors' or 'HA majors' based on mutually-agreed-upon decisions made by a pair of independent coders. The coders were told to consider a major an 'HE major' if it was (explicitly or implicitly) invested in the agenda of 'the socially powerful' (e.g. the wealthy). Majors designated as 'HE majors' included: accounting; business; business administration; business economics; business management; economics; 
marketing; and pre-economics. They were told to consider a major to be an 'HA major', on the other hand, if it was (explicitly or implicitly) invested in the interests of subordinate social groups (e.g. women, ethnic minorities). This category included: African languages; African studies; anthropology; Asian studies; ethnomusicology; Jewish studies; Latin American studies; Near Eastern studies; public health; sociology; special education; and women's studies.

Having made these classifications, the authors then compared students from each type of major on anti-egalitarianism-as measured by both the social dominance orientation scale (see Pratto et al., 1994) and the symbolic racism scale (see Henry \& Sears, 2002; Sears, van Laar, Carrillo, \& Kosterman, 1997), while also controlling for demographic differences such as gender and ethnicity. As expected, and within every year of study examined, 'HE majors' were found to have attitudes significantly more antiegalitarian than were 'HA majors'.

Kurpius and Lucart (2000) found a similar pattern when they compared men enrolled as civilian university students with men enrolled as US military students-in the Naval Academy, Air Force Academy, or Reserve Officer Training Corps. In this research, the civilian students were pursuing various courses of study, and can thus be thought of as a control group. The military students, by contrast, were all joining up with a clearly HE system. In line with SDT, this research found the military students to have relatively anti-egalitarian attitudes when compared to their civilian counterparts. Specifically, the military men-relative to the civilians-were likely to hold negative attitudes toward women (e.g. to feel that women's rights should be curtailed), to endorse masculinity norms (e.g. to agree that men should act 'tough'), and to show higher levels of rightwing authoritarianism.

Along the same lines, Liebkind and Eränen (2001) found differences between nursing students and police academy students in terms of their attitudes toward fictional trauma victims (e.g. refugees, victims of shipwreck). Notably, both groups of students were aspiring to professional careers in which they would meaningfully interact with such victims, albeit in different ways. In line with SDT expectations, however, these groups expressed divergent attitudes toward the fictional victims. Students of the police academy (in training for HE work) expressed relatively negative attitudes toward the victims, while nursing students (who were following an HA career track) expressed relatively positive attitudes. Police students were less likely than their nursing counterparts, for example, to find the victims interesting or likable. While this same study did not find a similar set of differences among medicine, law, and social sciences students, the latter groupas we would expect-tended to show the most favorable attitudes toward the victims.

Research from non-student populations tells a similar story. Sidanius, Liu et al. (1994), for example, examined social dominance orientation across four different groups of people: (1) police officers from the (HE) Los Angeles Police Department; (2) public defenders from the (HA) Los Angeles Public Defenders Office; (3) undergraduate students from UCLA (following both HE and HA tracks); and (4) adults called to jury duty in Los Angeles County (from both HE and HA organizations). It was predicted that the police officers, operating within an HE organization, would show higher levels of social dominance orientation than either the undergraduates or the jurors. Similarly, it was predicted that the public defenders, working within an HA organization, would show lower levels of social dominance orientation than either of these groups. Both of these differences emerged, and were statistically significant. Impressively, these differences remained significant even after researchers controlled for demographic factors that differed across the groups (e.g. age, gender, social class, education).

Whitehead (1998) nicely illustrated a similar pattern with respect to death penalty viewsdocumenting the different death penalty views of public defenders, district attorneys, and legislators. Consistent with work on social dominance orientation, it was found that public defenders were the most likely to oppose the death penalty, to express concerns about 
its morality, and to believe that it fails as a deterrent. Further, public defenders were also the most likely of the three groups to believe that the death penalty is imposed in a 'racially' biased manner, and to argue that death penalty laws should strive to guarantee the absence of 'racial' bias. In short, across a variety of populations and measures, research strongly supports the idea that there is a tendency for people to match up with institutions that share their sociopolitical views.

What processes are responsible for this 'matching' of the social dominance orientation (and related constructs) of individuals to congruent social institutions? Do people tend to seek out and remain in institutions that ' $\mathrm{fit}$ ' them sociopolitically? Or do organizations select, breed, and work to retain those who best 'fit' their sociopolitical climate? As mentioned earlier, social dominance theorists have proposed that several distinct processes are at work in creating this 'fit' (see van Laar et al., 1999): self-selection, institutional selection, institutional socialization, differential rewards, and differential attrition rates.

It is important to note that social dominance theorists' conceptualization of these processes both echoes and coheres with existing models in the organizational and vocational choice literature. For example, social dominance theorists suspect, as suggested by Bretz and Judge's (1994) theory of work adjustment, that person-organization congruence fuels successful and effective work relations, at least in part because those who most strongly identify with an organization are also those most likely to take on an organization's perspective and act in its best interests (e.g. see Dutton, Dukerich, \& Harquail, 1994; Mael \& Ashforth, 1992). Social dominance theorists also suggest, as Holland $(1959,1966)$ first did, that the processes driving congruence are intertwined (i.e. non-mutually exclusive). Reward systems, for example, are likely to be associated with turnover rates. Further, and most notably, social dominance theorists' views are consistent with the attraction-selection-attrition model developed by Schneider (1987), which argues that both individuals' inclinations and organizations' preferences play into creating and maintaining person-organization congruence.

The five processes proposed to drive sociopolitical P-E congruence constitute our focus for the remainder of this paper. We discuss each of these processes in turn, and review research that bears on each. We begin by discussing the process of self-selection, and then turn to institutional selection, institutional socialization, differential rewards, and finally differential attrition rates.

\section{Self-selection}

Self-selection, put simply, is the process by which people select their environments. This could entail, for example, a college student selecting his or her major, a recent graduate deciding which company to work for, or a seasoned professional choosing among his or her most recent job offers. It will be recalled that the organizational and vocational literature on value congruence suggests that people tend to select environments that 'fit' their work-related values. In a similar fashion, SDT suggests that people tend to select environments that 'fit' their sociopolitical views. More specifically, all else being equal, those with discriminatory or anti-egalitarian values should gravitate toward HE institutions such as police departments or financial firms, while those with more egalitarian values should instead be attracted to HA institutions such as human rights organizations.

This pattern of self-selection is precisely what has been found. Sidanius et al. (1996) provided initial early evidence for this pattern in a study that examined the relationship between social dominance orientation and career interests among UCLA undergraduate students. The researchers asked students to rate the attractiveness of four relatively HE careers (government prosecutor, law enforcement officer, FBI agent, and big businessperson) as well as four relatively HA careers (civil rights lawyer, lawyer in defense of the poor, human rights advocate, and worker at a charitable organization). As expected, students' levels of social dominance orientation were positively correlated with their liking for the HE careers and negatively 
correlated with their liking for the HA careers-even after researchers controlled for students' socioeconomic status and level of political conservatism. In other words, those with anti-egalitarian values expressed greater interest in HE careers like law enforcement officer, while those with more egalitarian views were more enticed by HA careers like civil rights lawyer. It is worth noting that these effects have been fully replicated; in a study using Stanford University undergraduates, Pratto et al. (1997, Experiments 1 \& 2) found precisely the same relationship between social dominance orientation and career interests.

Sidanius et al. (2003) found additional evidence of self-selection when they examined UCLA students' attitudes as a function of their career aspirations. In this research, the authors generated lists of careers that could be clearly designated as either 'HE careers' or 'HA careers'. Among the 'HE careers', they listed: economist; financial manager; military personnel; national security officer; and police officer. And among the 'HA careers' were: social scientist; social worker; and special education teacher. Students were asked to indicate their interest in pursuing each type of career, and the authors then examined the relationship between students' career interests and levels of anti-egalitarianism. As predicted, students who were attracted to 'HE careers' had significantly higher than average anti-egalitarianism scores than those who were attracted to 'HA careers'. Even more striking was the temporal sequence of this relationship: students' level of antiegalitarianism was significantly predictive of their later interest-up to a year or more laterin 'HE careers' versus 'HA careers'. While this research, like that conducted by Sidanius et al. (1996), is limited by the fact that it uses only student samples, its findings are quite supportive of the idea that self-selection contributes to the congruencies observed between antiegalitarianism, on the one hand, and academic and career aspirations, on the other.

\section{Institutional selection}

The second process thought to underlie sociopolitical P-E congruence is institutional selection.
Just as people appear to be drawn toward organizational environments that 'match' their basic values, so too do organizations seem inclined to recruit and select attitudinal 'matches'. It is posited that institutions will be inclined to do this because they will function most smoothly and effectively when their own values are mirrored in their employees. In the organizational literature on work values, it has been found that recruiters' and interviewers' assessments of potential employees' 'fit' are important determinants of hiring decisions (see, e.g. Bretz, Rynes, \& Gerhart, 1993; Cable \& Judge, 1997). In the same vein, SDT predicts that HE organizations should be inclined to recruit relatively anti-egalitarian-minded individuals, while HA organizations should instead be relatively inclined to recruit egalitarian-minded individuals.

Pratto et al. (1997, Experiments 3 \& 4) found experimental evidence for such institutional selection in studies that simulated employment scenarios. In these studies, undergraduate students and businesspeople-armed with a set of job descriptions and a set of resumés-were asked to play the role of hiring employer. The job descriptions that the students were given described either HE positions or HA positions, but were otherwise indistinguishable (e.g. they bore the same titles, entailed the same duties, and offered the same salaries). Similarly, while the resumés that the students were given included information either about the candidate's past HE experience or past HA experience, they were otherwise comparable. For example, one (HE) resumé listed work as a camp counselor at an elite private camp in Lake Tahoe and involvement in 'Capital Operations', a student club promoting free enterprise in Eastern Europe and Russia; a comparable (HA) resumé listed work as a camp counselor at a Head Start program in San Francisco and involvement in 'Life Savers', a student club promoting international legal protections for rainforests.

A series of pre-tests confirmed that applicants saw candidates with past HE experience (like the Lake Tahoe counselor) as having rather high levels of social dominance orientation and 
candidates with past HA experience (like the Head Start counselor) as having rather low levels of social dominance orientation. Moreover, in addition to 'matching' candidate experiences with assumed sociopolitical attitudes in a manner consistent with SDT predictions, simulated employers also tended to recommend applicants with seemingly high levels of social dominance orientation for HE positions, and applicants with seemingly low levels of social dominance orientation for HA positions.

It is also worth noting two interesting results from a related study by Pratto and Espinoza (2001). Pratto and Espinoza found a sex bias among white job candidates: simulated employers tended to recommend more white men for HE positions and more white women for HA positions (an effect also found by Pratto et al., 1997). Moreover, a 'racial' bias was also observed: Whites tended to be selected for the HE positions, while blacks and Latinos tended to be selected for the HA positions. Importantly, both the sex bias and the 'racial' bias are consistent with the idea of creating a 'match' between anti-egalitarian attitudes and type of position (HE or HA) since men have reliably higher average levels of social dominance orientation than do women (Pratto et al., 2000; Sidanius, Levin, Liu, \& Pratto, 2000; Sidanius \& Pratto, 1999; Sidanius, Pratto, \& Bobo, 1994; see also Sidanius, Pratto, \& Brief, 1995) and since whites have reliably higher average levels of social dominance orientation than do either blacks or Latinos (Pratto, 1999; Sidanius, Pratto, \& Rabinowitz, 1994).

In sum, in addition to evidence suggesting that people are attracted to institutions that 'fit' them sociopolitically (i.e. evidence of selfselection), there is also evidence suggesting that the attraction is mutual. As predicted by SDT, it appears that HE institutions, looking to fill HE positions, are more likely to seek out individuals with anti-egalitarian attitudes, while HA institutions, looking instead to fill HA positions, will search for individuals with egalitarian attitudes.

\section{Institutional socialization}

SDT further expects that institutional socialization fuels the compatibility between people's sociopolitical attitudes and the environments that they end up in. Institutional socialization can be defined as the process by which people's values and attitudes are shaped by forces like institutional rules, institutional incentives, and peer pressures. Beginning with Newcomb's (1943) classic Bennington studies, much research has looked at the question of whether and how institutions might affect individuals' sociopolitical attitudes. Newcomb and his colleagues found that students' attitudes dramatically swung toward the liberal end of the political spectrum during the college years, and then remained more or less stable for the next 50 years (Alwin, Cohen, \& Newcomb, 1991). While we cannot expect that institutional socialization will always be this powerful, a good deal of research shows that HE and HA institutions tend to enhance or attenuate people's antiegalitarian attitudes, respectively.

For example, there is some evidence that American higher education (on the whole a relatively HA system) has HA effects on students' sociopolitical views. Both cross-sectional and longitudinal studies show that prejudice against subordinate groups tends to decrease with increasing exposure to higher education (e.g. Bobo \& Licari, 1989; Pascarella, Edison, Amaury, Serra, \& Terenzini, 1996; Sidanius et al., 1991; Sinclair, Sidanius, \& Levin, 1998). Research by Sinclair et al. (1998), for example, found such a tendency among 1,623 students at UCLA. Sinclair et al. measured students' attitudes just prior to enrollment and then again upon completion of their freshman year. After nine months of exposure to the university environment, it was found that students became reliably less group-dominance oriented, less 'racist', less opposed to the egalitarian distribution of social resources, and less opposed to welfare for the poor. Similarly, in line with our expectations, Pascarella and colleagues (1996) found that-to the extent that students perceive their school to be open to 'racial' / ethnic diversity-the college experience is likely to increase students' openness to such diversity. 
More evidence for this process of institutional socialization was found by Sidanius et al. (1991), who looked at a sample of 5,655 undergraduate students at the University of Texas at Austin (UT). In this research, Sidanius and colleagues reasoned that the university as a whole could be classified as an HA organization, but that one could nonetheless distinguish between HE lines of study (e.g. business) and HA lines of study (e.g. sociology). They therefore expected that exposure to the university, in general, would promote egalitarianism. In addition, they expected that a student's course of study (HE or HA) would interact with this overall positive shift in egalitarianism; while an HE course of study was predicted to retard this shift, an HA course was predicted to augment it.

The results confirmed these expectations. As a group, the more students were exposed to UT, the less 'racially' prejudiced they became. The size of this shift, however, varied by student major. Given the same amount of university exposure, students with HE majors showed a significantly smaller decrease in prejudice than did students with HA majors. Thus, both the macro-environment (the university as a whole) and the micro-environment (the context of student major) appeared to play a role in determining changes in students' 'racial' prejudices. Importantly, this finding is very much in agreement with recent research in education showing that majoring in traditional fields like business and science may detract from a college or university's efforts to promote 'racial' understanding among students (e.g. see Astin, 1993).

Other studies have reported similar findings. For example, Guimond and Palmer (1996) found a pattern consistent with SDT when they compared students studying commerce (and thus following an HE track) with students studying social sciences (and thus following an HA track). These authors found that, across two and a half years within their respective fields of study, commerce students and social science students both changed their beliefs about poverty and unemployment-but in opposite directions. While the commerce students became increasingly likely to explain poverty and unemployment in terms of internal attributions (e.g. laziness), the social science students became increasingly likely to explain these phenomena in terms of external attributions (e.g. lack of opportunity; see also Guimond et al., 1989).

More recently, Dambrun, Guimond, and Duarte (2002) found evidence for field-specific socialization among French university students. In this research, students studying psychology were compared with students in the relatively HE-oriented field of law. In line with SDT predictions, psychology students, as compared with law students, showed significantly lower levels of social dominance orientation and significantly less endorsement of stereotypes about a subordinate group (French Arabs). Moreover, psychology students were significantly more likely to say that they perceived egalitarian norms regarding tolerance within their major. Moreover, the effect of students' field of study on stereotyping (though not on social dominance orientation) was mediated by this measure of perceived social norms.

Similar research has been conducted outside of the traditional liberal arts university setting. For instance, Guimond (2000) examined attitudes among prospective officers at a (HE) Canadian military college across a four-year period. In line with SDT, as their training progressed, Anglophone (majority) students became significantly more negative toward outgroups (e.g. Francophones, civilians, and immigrants) and significantly more likely to believe in the legitimacy of the economic gap between Francophones and Anglophones. Greater exposure to the HE environment was thus clearly associated with increases in antiegalitarian attitudes.

In another study of Canadian military students, Guimond (1999) found that, with increased exposure to their HE environment, students became increasingly politically conservative. For example, they became more likely to support punitive law enforcement practices, more likely to make internal attributions (e.g. to laziness) in explaining poverty and unemployment, and more likely to report negative 
attitudes toward subordinate outgroups (homosexuals, convicts, and ex-convicts). Further, as was the case with research on non-military students, the size of this general trend depended upon students' majors. Specifically, it was found that engineering students (HE majors) became significantly more conservative across time than did humanities or social science students (HA majors).

Other research has examined socialization within the workplace, particularly the police force. As SDT would expect, this research largely suggests that the law enforcement system (an unambiguously HE organization) breeds anti-egalitarian, authoritarian, and xenophobic attitudes among police officers. Early work by McNamara (1967), for example, followed officers from the recruit stage through two years on the job. McNamara found that officers' authoritarianism (which was positively correlated with endorsement of the use of force) increased across time. Similarly, Teahan (1975) found that across just 18 months of police training, white recruits became progressively more hostile toward blacks (see also Carlson \& Sutton, 1974). Along the same lines, Genz and Lester (1976) found that municipal officers, in general, had higher levels of authoritarianism than did officers with less than a year of experience. And Hageman (1979) and Carlson and Sutton (1975) found a positive association between officers' authoritarianism and their time on the job.

Interestingly, even when police are specifically trained in 'anti-racism' and in appreciation of subordinate cultures, the usual socializing effects of the police force still appear to operate. For example, when Wortley and Homel (1995) studied 412 Australian recruits who had participated in such training vis-a-vis Aborigines, they found that despite a softening of authoritarianism during the training phase, within 12 months' time in the field recruits had nonetheless become significantly more ethnocentric and authoritarian than they were prior to training. While these studies do not always rule out alternative explanations-particularly the possibility that there are different rates of attrition for different types of people-they are consistent with the predicted pattern (see also Chin \& Wells, 1998).

Finally, it is important to mention that there have also been a few failures to replicate the predicted pattern. Peterson and Lane (2001), for example, found no evidence of differential change in authoritarianism between students in professional schools (HE majors) and students in the social sciences and humanities programs (HA majors) across four years. Instead, these researchers found that there were decreases in authoritarianism across the college years that were essentially the same for both sets of students. While these findings are not necessarily at odds with SDT (e.g. it is possible that the macro-environment was in this case unusually salient), they point up the need for additional research on socialization effects.

\section{Differential success}

Social dominance theorists argue that institutions are invested in maintaining P-E 'fits' in terms of sociopolitical attitudes. As we have seen, this argument is generally consistent with research on institutional selection suggesting that employers are more likely to express interest in sociopolitical 'matches' than in sociopolitical 'mismatches'. And as will be recalled, this argument meshes nicely with the extensive organizational literature suggesting that P-E 'fit' with respect to work values boosts employee performance. Research that has looked at people's behavior in HE versus HA settings as a function of sociopolitical attitudes is also generally supportive of this view.

In his classic studies of obedience to authority, for example, Milgram (1974) found that subjects high in authoritarianism were somewhat more likely than others to obey experimenters and-ostensibly-to harm innocent people by administering painful electrical shocks. Were Milgram, say, the head of an organization devoted to the torture of others, it would clearly be in his interest to seek out and reward employees with an authoritarian bent. In short, since sociopolitical 'matches' should tend to be an institution's most effective players, it makes sense to predict that institutions will tend to reward these 
'matches' more than other individuals. In other words, all else being equal, rewards like positive performance ratings, high salaries, and high rates of promotion should tend to go to employees with congruent sociopolitical attitudes rather than to employees with role-incongruent sociopolitical attitudes.

Research conducted by van Laar et al. (1999) supports this line of reasoning. This research, based on a large sample of college students, examined the relationship between students' sociopolitical 'fit' with their majors and students' grade point averages (GPAs). The authors distinguished among three types of academic majors: HE majors, HA majors, and 'neutral' majors. As anticipated, they found that there was a basic 'fit' between students' majors and students' sociopolitical attitudes; specifically, HE majors tended to have high 'racism' scores, HA majors tended to have low 'racism' scores, and 'neutral' majors tended to have intermediate 'racism' scores.

Based on the combination of type of major and 'racism' score, the authors then classified students as either 'congruents' or 'incongruents'. Highly anti-egalitarian-minded students, with 'racism' scores in the top third of the total student distribution, were classified as 'congruents' if they were HE majors and as 'incongruents' if they were HA majors. By contrast, highly egalitarian-minded students, with 'racism' scores in the bottom third of the total distribution, were classified as 'congruents' if they were HA majors and as 'incongruents' if they were HE majors. Other students (students with 'neutral' majors) were excluded from analyses. It was expected that, all else being equal, 'congruents' would receive greater institutional rewards, in the form of higher GPAs, than would 'incongruents'. In line with this expectation, while most 'incongruents' received less than a ' $\mathrm{C}$ ' average, most 'congruents' received above a ' $\mathrm{C}$ ' average. Importantly, this pattern held even after controlling for 'racism', college major, ethnicity, political conservatism, and year in school.

These results were replicated and extended in recent research (Sidanius et al., 2003) that made use of a large panel study of UCLA students. Consistent with the findings of van Laar et al. (1999), this research found that students who were 'congruent'-in terms of their career paths and anti-egalitarianism scores-also tended to enjoy relatively high academic success. As compared with 'incongruents', 'congruents' had higher GPAs and more positive subjective feelings about their academic prowess.

Moreover, and interestingly, this pattern was foreshadowed by students' expectations of academic success even before they had committed to different majors. Specifically, when students expected that they would study an 'HE major', increasing levels of anti-egalitarianism were associated with increased intellectual selfconfidence. When students expected that they would study an 'HA major', on the other hand, increasing levels of anti-egalitarianism were instead associated with decreased intellectual selfconfidence. Thus, not only did 'congruents' again tend to excel relative to 'incongruents', but it appears that 'incongruents' were handicapped from the start by lower intellectual selfconfidence.

Importantly, research has also uncovered evidence for the process of differential success within the police force. For example, Leitner and Sedlacek (1976) found that the more 'racially' prejudiced police officers were, the more likely they were to receive positive performance evaluations from their supervisors. A similar pattern was more recently observed in a comprehensive investigation of the Los Angeles Police Department (Christopher et al., 1991), conducted in the wake of the Rodney King police brutality case. Investigators reviewed the personnel files of the 44 police officers who had the greatest number of civilian complaints for brutality, use of excessive force, and use of improper tactics. Consistent with Leitner and Sedlacek's findings, performance reviews of these officers were found to be unusually positive and unusually optimistic regarding the officers' future prospects on the force. While more research needs to be done on the process of differential success, the available findings are therefore just as SDT would expect. 


\section{Differential attrition}

As will be recalled, past research on value congruence has repeatedly shown a link between P-E 'fit' and turnover. Such research has found that people who share the values of their organizations are more satisfied, more committed, and less likely to quit or drop out than are their incongruent counterparts. As Chan (1996, p. 199) put it: 'Over time, individuals in cognitive misfit are likely to be less motivated, less committed, and experience more workrelated stress and job dissatisfaction than those in fit', a process that should affect not just an individual's turnover intentions, but also the likelihood that an individual will suffer when it comes to salary, promotion, and layoff decisions (e.g. see Milkovich \& Wigdor, 1991).

In addition, research has suggested that the degree to which people socially identify with an organization-the degree to which their selfconcepts are tied up with their organizational memberships-can importantly affect voluntary turnover decisions (e.g. Ashforth \& Mael, 1989; Mael \& Ashforth, 1995). Mael and Ashford (1995), for example, in a study of 1,082 US Army recruits, found that identification predicted subsequent attrition across a two-year period, net of various personality and demographic variables. Given these kinds of findings, and given the apparent link between sociopolitical congruence and institutional success, it is logical to expect that sociopolitical congruence will also relate to turnover. That is, those with strong egalitarian attitudes should tend to stay in HA organizations but leave HE organizations, while those with strong anti-egalitarian attitudes should tend to do the opposite.

Although little research speaks directly to this claim, there is related research that is suggestive. For example, in a study of hospital personnel, Sims \& Kroeck (1994) found a link between P-E 'fit' in terms of ethics and turnover rates. In this study, it was found that the more comfortable employees were with the hospital's ethical climate, the more likely they were to express organizational commitment and the less likely they were to indicate turnover intentions. Another study (Schwepker, 1999) found the same positive effects for salespeople who perceived a match between their own ethical beliefs and those of top management. Because egalitarian beliefs might reasonably be expected to relate to people's ethical beliefs, these studies should increase our confidence in a potential link between sociopolitical 'fit' and turnover.

Research by van Laar et al. (1999), while not at all conclusive, offers further suggestive evidence. This research suggests that there may be differential attrition rates for college students who 'fit' with their majors sociopolitically versus those who do not. More specifically, van Laar et al. found that as students progressed from their freshman year to their junior year, their 'racial' prejudice scores (high or low) were increasingly likely to 'match' with the nature of their chosen major (HE or HA). Among the freshmen, 'incongruents' outnumbered 'congruents'. By the time the students were juniors, however, the reverse was true. Institutional socialization may well have been responsible for this shift across time. It is a strong possibility, however, that differential attrition (to other majors or even out of the university system altogether) also or instead played a key role. Unfortunately, the measures available in the study did not allow the researchers to test the relative validity of these possibilities.

\section{Conclusions and future directions}

In integrating the extensive literature on value congruence with the tenets of SDT, it has been argued here that there is a P-E 'fit' for sociopolitical attitudes within both academic and occupational settings. According to this argument, people who endorse societal hierarchies-for example by holding 'racist' views or attributing poverty to 'laziness'-tend to be found in institutional settings that function to build and maintain group-based social hierarchies (known as HE institutions). People who endorse egalitarianism, on the other hand, tend to be found in environments that function to attenuate hierarchies, or equalize conditions across groups (known as HA institutions).

In addition to making this basic claim, we have suggested that five non-mutually exclusive 
processes drive sociopolitical congruence: selfselection, institutional selection, institutional socialization, differential rewards, and differential attrition rates. Not only does existing research support the notion of sociopolitical P-E congruence, but existing work also provides evidence that each of the five processes contributes to this congruence.

Nevertheless, a number of questions remain to be addressed. In particular, because evidence for the process of differential attrition is both sparse and indirect, subsequent research needs to examine this process headon. Such research should assess whether-all else being equal-there is a link between P-E sociopolitical congruence, on the one hand, and attrition rates, on the other. Similarly, given the fact that Peterson and Lane (2001) did not replicate socialization effects for college students' majors, it is important that future research be done to determine why. Specifically, it would be useful to examine potential moderators of socialization (e.g. identification with one's setting) and also to look at different types of socialization (e.g. socialization arising from peer pressure versus institutional incentives).

Future research should also examine the extent to which people display workplacecongruent sociopolitical attitudes simply as an act of compliance. That is, when people indicate that they hold attitudes that are workplace-congruent, are they just (externally) acting in accordance with social pressures or do they actually internalize these attitudes? This question is, of course, functionally irrelevant to SDT (which does not differentiate between compliance and internalization in this context). Nonetheless, exploring such questions (e.g. by examining the extent to which people's reported attitudes and/or behaviors vary as a function of the presence of superiors versus peers) would certainly inform and deepen our understanding of socialization processes.

At a more general level, future research would do well to make use of experimental designs to examine the processes driving sociopolitical congruence. Such designs would allow researchers to more precisely isolate each of the five processes involved in P-E congruence, and to compare their relative influences. Importantly, experimental designs would also permit examination of the interactions, or interrelationships, among the different processes, as well as the causal directions of these various interrelationships-something which existing research is not able to address. For example, while it might be expected that selfselection processes precede socialization processes, it is also possible that anticipatory membership in an organization leads to an attitude change, such that socialization processes occur even before final self-selection decisions have been made.

Various other relationships among the processes also seem plausible; institutional selection, for example, is likely to impact selfselection; both socialization and rewards are likely to impact attrition; and attrition is likely to impact both future self-selection and future institutional selection. Examining these types of questions, along with examining related phenomena that may mediate or moderate relationships (e.g. motivation, perceived selfenvironment similarity) will be important in fleshing out our understanding of P-E sociopolitical 'fit'.

As a central goal, research should also examine precisely how the processes identified here work to create broad-based HE and HA institutions, like universities, law enforcement systems, and health care conglomerates, and how such institutions in turn serve to maintain existing social hierarchies. That is, given that one of the most basic arguments put forward here is that institutions play a key role in sustaining, enhancing, and/or dismantling societal inequalities, an important task for future researchers in this area is to delineate the connections among P-E 'fit', the general tenor of organizations in terms of their stance toward egalitarianism, the balance of $\mathrm{HE}$ and HA forces within society, and the resulting existence of hierarchy within society. 


\section{Notes}

1. While a discussion of the limiting conditions of social dominance theory and its relationships to competing and related theoretical perspectives is beyond the scope of this paper, these questions are comprehensively discussed elsewhere (see Huddy, 2004; Jost, Banaji, \& Nosek, 2004; Banaji, 2004; Reicher, 2004; Rubin \& Hewstone, 2004; and Sidanius, Pratto, van Laar, \& Levin, 2004).

2. The precise manner in which $\mathrm{HE}$ and HA organizations are identified in any given study has often been determined by the use of trained independent coders and assessed by the use of inter-rater reliability (see, e.g. Sidanius et al., 2003).

\section{Acknowledgment}

The authors would like to thank Nurcan Ensari and Michael Hogg for their valuable comments on earlier versions of this paper.

\section{References}

Adkins, C. L., Ravlin, E. C., \& Meglino, B. M. (1996). Value congruence between co-workers and its relationship to work outcomes. Group and Organization Management, 21, 439-460.

Adkins, C. L., Russell, C. J., \& Werbel, J. D. (1994). Judgments of fit in the selection process: The role of work value congruence. Personnel Psychology, 47, 605-623.

Altemeyer, B. (1998). The other 'authoritarian personality'. In M. P. Zanna (Ed.), Advances in experimental social psychology (Vol. 30, pp. 48-92). New York: Academic Press.

Alwin, D. F., Cohen, R. L., \& Newcomb, T. M. (1991). Political attitudes over the life span: The Bennington women after fifty years. Madison, WI: University of Wisconsin Press.

Ashforth, B. E., \& Mael, F. (1989). Social identity theory and the organization. Academy of Management Review, 14, 20-39.

Assouline, M., \& Meir, E. I. (1987). Meta-analysis of the relationship between congruence and well-being. Journal of Vocational Behavior, 31, 319-332.

Astin, A. W. (1993). What matters in college: Four critical years revisited. San Francisco: Jossey-Bass.

Ben-Shem, I., \& Avi-Itzhak, T. E. (1991). On work values and career choice in freshmen students: The case of helping vs. other professions. Journal of Vocational Behavior, 39, 369-379.
Bobo, L., \& Licari, F. (1989). Education and political tolerance. Public Opinion Quarterly, 53, 285-308.

Boxx, W. R., Odom, R. Y., \& Dunn, M. G. (1991). Organizational values and value congruency and their impact on satisfaction, commitment, and cohesion: An empirical examination within the public sector. Public Personnel Management, 20, 195-205.

Bretz, R. D., \& Judge, T. A. (1994). Person-organization fit and the theory of work adjustment: Implications for satisfaction, tenure, and career success. Journal of Vocational Behavior, 44, 32-54.

Bretz, R. D., Rynes, S. L., \& Gerhart, B. (1993). Recruiter perceptions of applicant fit: Implications for individual career preparation and job search behavior. Journal of Vocational Behavior, 43, 310-327.

Cable, D., \& Judge, T. (1996). Person-organization fit, job choice decisions, and organizational entry. Organizational Behavior and Human Decision Processes, 67, 294-311.

Cable, D. M., \& Judge, T. A. (1997). Interviewers' perceptions of person-organization fit and organizational selection decisions. Journal of Applied Psychology, 82, 546-561.

Carlson, H. M., \& Sutton, M. S. (1974). The development of attitudes as a function of police roles. Personality and Social Psychology Bulletin, 1, 113-115.

Carlson, H. M., \& Sutton, M. S. (1975). The effects of different police roles on attitudes and values. Journal of Psychology, 91, 57-64.

Chan, D. (1996). Cognitive misfit of problem-solving style at work: A facet of person-organization fit. Organizational Behavior and Human Decision Processes, 68, 194-207.

Chatman, J. A. (1989). Improving interactional organizational research: A model of person-organization fit. Academy of Management Review, 14, 333-349.

Chatman, J. A. (1991). Matching people and organizations: Selection and socialization in public accounting firms. Administrative Science Quarterly, 36, 459-484.

Chatman, J. A., \& Barsade, S. G. (1995). Personality, organizational culture, and cooperation: Evidence from a business simulation. Administrative Science Quarterly, 40, 423-443.

Chevigny, P. (1995). The edge of the knife: Police violence in the Americas. New York: New Press.

Chin, G. J., \& Wells, S. C. (1998). The 'blue wall of silence' as evidence of bias and motive to lie: A 
new approach to police perjury. University of Pittsburgh Law Review, 59, 233.

Christopher, W. A., Argellas, J. A., Barnes, W. R., Estrada, L. F., Kantor, M., Mosk, R. M. et al. (1991). Report of the independent commission on the Los Angeles police department. Los Angeles: Independent Commission on the Los Angeles Police Department.

Cole, D. (1999). No equal justice: Race and class in the American criminal justice system. New York: New Press.

Dambrun, M., Guimond, S., \& Duarte, S. (2002). The impact of hierarchy-enhancing vs. attenuating academic major on stereotyping: The mediating role of perceived social norm. Current Research in Social Psychology, 7, 114-136.

Dutton, J. E., Dukerich, J. M., \& Harquail, C. V. (1994). Organizational images and member identification. Administrative Science Quarterly, 39, 239-263.

Feldman, K. A., \& Newcomb, T. M. (1969). The impact of college on students. San Francisco: Jossey-Bass.

Genz, J. L., \& Lester, D. (1976). Authoritarianism in policemen as a function of experience. Journal of Police Science and Administration, 4, 9-13.

Goodman, S. A., \& Svyantek, D. J. (1999). Person-organization fit and contextual performance: Do shared values matter? Journal of Vocational Behavior, 55, 254-275.

Gottfredson, G. D., \& Holland, J. L. (1990). A longitudinal test of the influence of congruence: Job satisfaction, competency utilization, and counterproductive behavior. Journal of Counseling Psychology, 37, 389-398.

Guimond, S. (1999). Attitude change during college: Normative or informational social influence? Social Psychology of Education, 2, 237-261.

Guimond, S. (2000). Group socialization and prejudice: The social transmission of intergroup attitudes and beliefs. European Journal of Social Psychology, 30, 335-354.

Guimond, S., \& Palmer, D. L. (1996). The political socialization of commerce and social science students: Epistemic authority and attitude change. Journal of Applied Social Psychology, 26, 1985-2013.

Guimond, S., Palmer, D. L., \& Bégin, G. (1989). Education, academic program and intergroup attitudes. Canadian Review of Sociology and Anthropology, 26, 193-216.

Hageman, M. J. (1979). Who joins the force for what reasons: An argument for 'the new breed'. Journal of Police Science and Administration, 4, 9-13.

Henry, P. J., \& Sears, D. O. (2002). The symbolic racism 2000 scale. Political Psychology, 23, 253-283.
Holland, J. L. (1959). A theory of vocational choice. Journal of Counseling Psychology, 6, 35-44.

Holland, J. L. (1966). The psychology of vocational choice. Waltham, MA: Blasidell.

Holland, J. L. (1985). Making vocational choices: A theory of vocational personalities and work environments. Englewood Cliffs, NJ: Prentice-Hall.

Holland, J. L. (1996). Exploring careers with a typology: What we have learned and some new directions. American Psychologist, 51, 397-406.

Huddy, L. (2004). Contrasting theoretical approaches to intergroup relations. Political Psychology, 25, 947-967.

Jehn, K. A., Chadwick, C., \& Thatcher, S. M. B. (1997). To agree or not to agree: The effects of value congruence, individual demographic dissimilarity, and conflict on workgroup outcomes. International Journal of Conflict Management, 8, 287-305.

Jones, J. M. (1997). Prejudice and racism (2nd ed.). New York: McGraw-Hill.

Jost, J. T., \& Banaji, M. R. (2004). A decade of system justification theory: Accumulated evidence of conscious and unconscious bolstering of the status quo. Political Psychology, 25, 881-919.

Joyce, W., \& Slocum, J. (1982). Correlates of climate discrepancy. Human Relations, 35, 951-972.

Kemelgor, B. H. (1982). Job satisfaction as mediated by the value congruity of supervisors and their subordinates. Journal of Occupational Behaviour, 3, 147-160.

Kennedy, R. (1997). Race, crime and the law. New York: Vintage.

Kuo, C., Cheng, B., \& Wang, C. (2001). Value-fit, job personality, and worker effectiveness: An analysis of incremental validity. Chinese Journal of Psychology, 43, 175-187.

Kurpius, S. E. R., \& Lucart, A. L. (2000). Military and civilian undergraduates: Attitudes toward women, masculinity, and authoritarianism. Sex Roles, 43, 255-265.

Leitner, D. W., \& Sedlacek, W. E. (1976). Characteristics of successful campus police officers. Journal of College Student Personnel, 17, 304-308.

Liebkind, K., \& Eränen, L. (2001). Attitudes of future human service professionals: The effects of victim and helper qualities. Journal of Social Psychology, 141, 457-475.

Mael, F. A., \& Ashforth, M. E. (1992). Alumni and their alma mater: A partial test of the reformulated model of organizational identification. Journal of Organizational Behavior, 13, 103-123. 
Mael, F. A., \& Ashforth, B. E. (1995). Loyal from day one: Biodata, organizational identification, and turnover among newcomers. Personnel Psychology, 48, 309-333.

Mauer, M. (1999). Race to incarcerate. New York: New Press.

McNamara, J. H. (1967). Uncertainties in police work: The relevance of police recruits' backgrounds and training. In D. Bordua (Ed.), The police: Six sociological essays (pp. 163-252). New York: Wiley.

Meglino, B. M., Ravlin, E. C., \& Adkins, C. L. (1989). A work values approach to corporate culture: A field test of the value congruence process and its relationship to individual outcomes. Journal of Applied Psychology, 74, 424-432.

Meir, E. I. (1995). Elaboration of the relation between interest congruence and satisfaction. Journal of Career Assessment, 3, 341-346.

Milgram, S. (1974). Obedience to authority. New York: Harper \& Row.

Milkovich, G. T., \& A. K. Wigdor (Eds.). (1991). Pay for performance: Evaluating performance appraisal and merit pay. Washington, DC: National Academy Press.

Miller, J. G. (1996). Search and destroy: African-American males in the criminal-justice system. New York: Cambridge University Press.

Mitchell, M., \& Sidanius, J. (1995). Social hierarchy and the death penalty: A social dominance perspective. Political Psychology, 16, 591-619.

Mount, M. K., \& Muchinsky, P. M. (1978). Person-environment congruence and employee job satisfaction: A test of Holland's theory. Journal of Vocational Behavior, 13, 84-100.

Nelson, J. (2000). Police brutality: An anthology. New York: Norton.

Newcomb, T. M. (1943). Personality and social change. New York: Dryden.

O'Reilly, C. A., \& Chatman, J. A. (1996). Culture as social control: Corporations, cults and commitment. In B. M. Barry \& L. L. Cummings (Eds.), Research in organizational behavior: An annual series of analytical essays and critical reviews (Vol. 18, pp. 157-200). Stamford, CT: JAI Press.

O'Reilly, C. A., Chatman, J. A., \& Caldwell, D. F. (1991). People and organizational culture: A profile comparison approach to assessing person-organization fit. Academy of Management Journal, 34, 487-516.

Parenti, C. (1999). Lockdown America: Police and prisons in the age of crisis. New York: Verso.

Pascarella, E., Edison, M., Amaury, H., Serra, L., \& Terenzini, P. (1996). Influences on students' openness to diversity and challenge in the first year of college. Journal of Higher Education, 67, 174-195.

Peterson, B. E., \& Lane, M. D. (2001). Implications of authoritarianism for young adulthood: Longitudinal analysis of college experiences and future goals. Personality and Social Psychology Bulletin, 27, 678-690.

Posner, B. Z. (1992). Person-organization values congruence: No support for individual differences as a moderating influence. Human Relations, 45, 351-361.

Posthuma, A. B., \& Navran, L. (1970). Relation of congruence in student-faculty interests to achievement in college. Journal of Counseling Psychology, 17, 352-356.

Pratto, F. (1999). The puzzle of continuing group inequality: Piecing together psychological, social and cultural forces in social dominance theory. In M. P. Zanna (Ed.), Advances in experimental social psychology (Vol. 31, pp. 191-263). New York: Academic Press.

Pratto, F., \& Espinoza, P. (2001). Gender, race, and power. Journal of Social Issues, 57, 763-780.

Pratto, F., Liu, J. H., Levin, S., Sidanius, J., Shih, M., Bachrach, H. et al. (2000). Social dominance orientation and the legitimization of inequality across cultures. Journal of Cross-Cultural Psychology, 31, 369-409.

Pratto, F., Sidanius, J., Stallworth, L. M., \& Malle, B. F. (1994). Social dominance orientation: A personality variable predicting social and political attitudes. Journal of Personality and Social Psychology, 67, 741-763.

Pratto, F., Stallworth, L., Sidanius, J., \& Siers, B. (1997). The gender gap in occupational role attainment: A social dominance approach. Journal of Personality and Social Psychology, 72, 37-53.

Reicher, S. (2004). The context of social identity: Domination, resistance and change. Political Psychology, 25, 921-945.

Rubin, M., \& Hewstone, M. (2004). Social identity, system justification, and social dominance: Commentary on Reicher, Jost et al., and Sidanius et al. Political Psychology, 25, 947-967.

Rynes, S. L., \& Gerhart, B. (1990). Interviewer assessments of applicant 'fit': An exploratory investigation. Personnel Psychology, 43, 13-35.

Schneider, B. (1987). The people make the place. Personnel Psychology, 40, 437-453.

Schwepker, C. (1999). Research note: The relationship between ethical conflict, organizational commitment and turnover intentions in the salesforce. Journal of Personal Selling Ẽ Sales Management, 19, 43-49. 
Sears, D. O., van Laar, C., Carrillo, M., \& Kosterman, R. (1997). Is it really racism? The origins of White Americans' opposition to race-targeted policies. Public Opinion Quarterly, 61, 16-53.

Sidanius, J., Levin, S., Liu, J. H., \& Pratto, F. (2000). Social dominance orientation and the political psychology of gender: An extension and cross-cultural replication. European Journal of Social Psychology, 30, 41-67.

Sidanius, J., Liu, J., Pratto, F., \& Shaw, J. (1994). Social dominance orientation, hierarchy-attenuators and hierarchy-enhancers: Social dominance theory and the criminal justice system. Journal of Applied Social Psychology, 24, 338-366.

Sidanius, J., \& Pratto, F. (1999). Social dominance: An intergroup theory of social hierarchy and oppression. New York: Cambridge University Press.

Sidanius, J., Pratto, F., \& Bobo, L. (1994). Social dominance orientation and the political psychology of gender: A case of invariance? Journal of Personality and Social Psychology, 67, 998-1011.

Sidanius, J., Pratto, F., \& Brief, D. (1995). Group dominance and the political psychology of gender: A cross-cultural comparison. Political Psychology, 16, 381-396.

Sidanius, J., Pratto, F., Martin, M., \& Stallworth, L. (1991). Consensual racism and career track: Some implications of social dominance theory. Political Psychology, 12, 691-721.

Sidanius, J., Pratto, F., \& Rabinowitz, J. (1994). Gender, ethnic status, ingroup attachment and social dominance orientation. Journal of Cross-Cultural Psychology, 25, 194-216.

Sidanius, J., Pratto, F., Sinclair, S., \& van Laar, C. (1996). Mother Teresa meets Genghis Khan: The dialectics of hierarchy-enhancing and hierarchy-attenuating career choices. Social Justice Research, 9, 145-170.

Sidanius, J., Pratto, F., van Laar, C., \& Levin, S. (2004). Social dominance theory: Its agenda and method. Political Psychology, 25, 845-880.

Sidanius, J., van Laar, C., Levin, S., \& Sinclair, S. (2003). Social hierarchy maintenance and assortment into social roles: A social dominance perspective. Group Processes $\mathcal{E}^{2}$ Intergroup Relations, 6, 333-352.

Sims, R., \& Kroeck, K. G. (1994). The influence of ethical fit on employee satisfaction, commitment and turnover. Journal of Business Ethics, 13, 939-947.
Sinclair, S., Sidanius, J., \& Levin, S. (1998). The interface between ethnic and social system attachment: The differential effects of hierarchy-enhancing and hierarchy-attenuating environments. Journal of Social Issues, 54, 741-757.

Teahan, J. E. (1975). A longitudinal study of attitude shifts among Black and White police officers. Journal of Social Issues, 31, 47-56.

Tokar, D. M., Fischer, A. R., \& Subich, L. M. (1998). Personality and vocational behavior: A selective review of the literature, 1993-1997. Journal of Vocational Behavior, 53, 115-153.

Tonry, M. (1995). Malign neglect: Race, crime and punishment in America. New York: Oxford University Press.

Tranberg, M., Slane, S., \& Ekberg, S. E. (1993). The relation between interest congruence and satisfaction: A metaanalysis. Journal of Vocational Behavior, 42, 253-264.

Vancouver, J. B., \& Schmitt, N. (1991). An exploratory examination of person-organization fit: Organizational goal congruence. Personnel Psychology, 44, 333-352.

van Laar, C., Sidanius, J., Rabinowitz, J., \& Sinclair, S. (1999). The three r's of academic achievement: Reading, 'riting, and racism. Personality and Social Psychology Bulletin, 25, 139-151.

Weitzer, R. (2000). Racialized policing: Residents perceptions in three neighborhoods. Law and Society Review, 34, 1-19.

Whitehead, J. T. (1998) 'Good ol' boys' and the chair: Death penalty attitudes of policy makers in Tennessee. Crime and Delinquency, 44, 245-256.

Wortley, R. K., \& Homel, R. J. (1995). Police prejudice as a function of training and outgroup contact: A longitudinal investigation. Law and Human Behavior, 19, 305-317.

Paper received 27 May 2004; revised version accepted 22 October 2004.

\section{Biographical notes}

HILlARY HALEY is a PhD candidate in the department of psychology at the University of California, Los Angeles (UCLA).

JIM SIDANIUS is a full professor at the University of California, Los Angeles, with appointments in both the department of psychology and the department of political science. 